Article

\title{
Community Resident's Opinions and Perceptions on the Effectiveness of Waste Management and Recycling Potential in the Umkhanyakude and Zululand District Municipalities in the KwaZulu-Natal Province of South Africa
}

\author{
Bonginkosi Robert Dlamini ${ }^{1}$, Isaac Tebogo Rampedi ${ }^{1, *}$ and Ayodeji Peter Ifegbesan ${ }^{2}$ \\ 1 Department of Geography, Environmental Management \& Energy Studies, University of Johannesburg, \\ P.O. Box 524, Auckland Park 2006, South Africa; bzr.dlamini@gmail.com \\ 2 Department of Arts and Social Sciences Education, Olabisi Onabanjo University, P.M.B, 2002, \\ Ago-Iwoye 120107, Nigeria; ayodeji.ifegbesan@gmail.com \\ * Correspondence: isaacr@uj.ac.za; Tel.: +27-11-559-2429
}

Received: 24 July 2017; Accepted: 30 September 2017; Published: 16 October 2017

\begin{abstract}
Despite new environmental laws and regulations in South Africa during the last two decades, especially around municipal solid waste management, there is little emphasis towards waste minimization through recycling. Whereas most waste management research in South Africa has focused on urban municipalities, not much is known regarding the effectiveness of waste management services and recycling challenges in rural areas. This paper reports on the effectiveness of waste management practices from the perspective of community residents in selected rural districts of the KwaZulu-Natal province. A random sample comprised of 333 community residents was selected for questionnaire-administered interviews. Based on the opinions and perceptions of respondents, the provision of waste management services is generally inadequate. Apart from the successful collection of domestic solid wastes $(66.7 \%)$ from households by municipalities, the collection of recyclable waste materials from illegal waste dumps (75\%) and from households (68.7\%) are not being adequately provided. Thus, levels of dissatisfaction regarding municipal collection services are very high (97.3\%) amongst respondents. Furthermore, systematic recycling initiatives that involve communities are largely non-existent and most $(96.7 \%)$ respondents lack relevant technical knowledge on waste recycling and how it can be carried out effectively through waste segregation at source and other processes.
\end{abstract}

Keywords: waste management; waste minimization; recycling; rural district municipalities; community residents; households; satisfaction levels; willingness to recycle; waste separation; municipal solid waste; benefits and barriers

\section{Introduction}

The negative impacts of poor municipal solid waste management and the need to minimise the amounts of such a waste stream are of concern for environmental management in many countries. This is especially true in developing countries, where ineffective municipal solid waste management is leading to poor sanitation, increased public health risk, and other environmental challenges regarding its collection, storage, transportation, and final disposal through landfilling [1-4]. The composition of municipal waste is heterogenous and varies amongst countries and regions. The composition of this waste stream is largely a function of differences in cultures and lifestyles, levels of industrialisation, standards of living, degrees of recycling, and other options to reduce it [5-7]. Internationally, municipal 
solid waste usually arises from educational, institutional, commercial, and residential community sources as well as open spaces and streets in a given municipal area, and includes a variety of throw-away items $[3,8,9]$. These items entail all kinds of papers, garden wastes, discarded foods, plastics, packaging wastes, discarded furniture and clothes, bottles, appliances and batteries $[2,10,11]$.

In South Africa, municipal solid waste is classified as general waste and is comprised of business waste, building and demolition waste, inert waste, and domestic waste [12]. This waste stream is increasing in both urban and rural areas due to accelerated population growth and economic activities [13]. Whereas the amount of municipal solid waste in 1997 was $42,230,000 \mathrm{~m}^{3}$ by volume, in 2010 it increased to $68,626,526 \mathrm{~m}^{3}$ [14]. Also, 97 million tons of municipal solid waste was disposed of in landfill facilities in 2011 without any form of recycling, inevitably placing large stresses on receiving waste disposal sites, apart from the negative environmental impacts associated with their daily operations [14]. Although this waste is regarded as useless and not needed at the point of final disposal, if recycled effectively, its quantities can be substantially decreased if its usable fraction can be recovered from the waste stream for reuse $[5-7,15]$. Hence, local governments should not only ensure that municipal solid waste is collected and disposed of in landfill sites in a cost effective and sanitary manner, but also ascertain that recoverable components are reused and recycled efficiently [16]. Effective municipal solid waste management and its minimization has proven to be a very complex function in many countries, however, and is dependent upon adequate institutional capacity, enforcement of environmental laws and regulations, cooperation and collaboration between municipal governments, as well as heightened public awareness amongst community residents [2,17-19].

Even so, in South Africa there are marked degrees of unevenness in the provision of waste management services amongst communities due to their geographical location and associated socio-economic characteristics $[12,13]$. Some of these discrepancies are ascribable to the impact of previous apartheid policies which enforced separate development priorities for different population groups based on race. In most cases, low income and rural areas are receiving poor waste management services that are inferior to high income areas [14]. The existence of these spatial inequalities necessitates recognition of the fact that South African municipalities have differentiated capabilities in the delivery of waste management services, especially if some uniformity in the scope and quality of municipal waste management services is to be achieved [20].

The political structure associated with municipalities in South Africa is organised into five different categories: (A) metropolitan municipalities (2\%); (B1) municipalities with the largest budgets (9\%); (B2) municipalities with larger populations and towns (12\%); (B3) municipalities with relatively small populations (47\%); and (B4) municipalities which are mainly rural (30\%) [14]. Whereas (A) metropolitan municipalities dispose of large amounts of municipal solid waste $(14,514,400$ tons/annum), others deal with relatively lower amounts, ranging from 3,269,364 tons per annum (B1-municipalities with larger populations and towns) to 1,162,490 tons per annum (B4-municipalities which are mainly rural) [14]. Furthermore, most metropolitan municipalities in South Africa have better resource endowments in terms of revenues and staff with appropriate qualifications and skills and have an enabling infrastructure, therefore the proportion of households that receive waste management services within their jurisdiction tends to be very high (80\%) [14]. By contrast, communities located in rural municipalities have limited access $(20 \%)$ to waste management services due to institutional and capacity constraints as well as socio-economic barriers [14]. Regardless of these discrepancies, Section 24 of the South African constitution states that all citizens have a right to an environment that is not detrimental to their health and wellbeing and to have the environment protected for present and future generations [21].

Therefore, providing adequate waste management services is the responsibility of all spheres of government so that all citizens have access to basic services. Two types of national legislation, namely the Local Government: Municipal Systems Act [22] and the National Environmental Management: Waste Act [14], are relevant towards the realisation of this constitutional mandate. The Local Government: Municipal Systems Act [22] maintains that municipalities must involve 
all local communities, whether urban or rural, through appropriate mechanisms, processes, and procedures; the goal being to achieve adequate performance management levels. The Act also compels municipalities to provide equitable access of waste management services to local communities in a financially and environmentally supportable approach [22]. Furthermore, the National Environmental Management: Waste Act [12] seeks to give effect to Section 24 of the South African Constitution, which makes provision for measures that aim to reduce the amount of wastes produced by human activities and also to ensure that such wastes are recovered, reused, and recycled in an environmentally friendly manner. As a result, local municipalities have executive authority in delivering services such as the removal, storage, transportation, and final disposal of municipal solid waste and they must comply with national and provincial standards. Some of these standards require the separation or segregation of municipal solid waste prior to collection, the proper management of landfill sites, as well as the prevention and control of littering. Municipalities must also provide containers that are accessible to the public for the collection of waste, including recyclable components [12]. Despite these legislative provisions, waste minimization through separation at source, recovery, and recycling are not yet accorded a top priority in line with the new regulatory and legal requirements in South Africa [13]. This shortcoming undermines the long-term goals of the zero-waste strategy, pollution prevention, sustainable solid waste management and ultimately sustainable development [15].

To date, there is very limited empirical research [23] on how local municipalities and communities in South Africa are responding to the new legislative and regulatory framework, which calls for integrated waste management, along with more public participation and increased waste recycling rates. Adopting an integrated waste management strategy means "integrated planning, implementation, monitoring, and review of these waste management measures to ensure sustainability and to prevent detrimental impacts on human health and the environment" [24]. Unlike the majority of previous waste management studies in South Africa, which focussed more on cities and urban district municipalities [23,25-27], this paper is based on local municipal performance from the perspective of households in predominantly rural areas.

According to Gopaul [28], South African rural areas are some of the poorest human settlements in the world, and they have limited access to employment and educational opportunities. Many of their communities live in severe poverty, squalor, and have limited development activities in terms of modern infrastructure such as telecommunications, water supply, roads, schools, industries and health facilities $[28,29]$. Consequently, their population structures are frequently skewed towards more women, as a larger proportion of job-seeking men are migrant workers in the cities and nearby towns, and even in other provinces such as the Western Cape and the Gauteng.

Very few scientific investigations [29] have been directed to the challenges of rural solid waste management and its minimization, although nearly $40 \%$ of South Africa's inhabitants still live in rural areas. Despite major historical impediments in the provision of effective municipal solid waste management in many areas of South Africa including large metropolitan municipalities, deep rural areas and many jurisdictions under traditional and tribal authorities face enormous challenges. Payments of municipal waste services by local inhabitants remain limited because most indigent households in these areas cannot afford such services due to high unemployment levels and rampant poverty [30]. Sources of income and livelihoods in such rural areas are mostly scarce and are derived mostly from government social grants and pensions for the elderly, cash remittances from migrant workers, farm jobs, as well as subsistence agriculture, especially the rearing of livestock. It is for this reason that, in 2001, a national policy on free basic services was introduced specifically to provide a range of services to vulnerable households, including the poorest communities in rural areas [30]. The national policy on basic refuse removal services also promote measures intended to educate and raise awareness levels within all municipalities regarding the proper handling of domestic solid waste as well as the need to minimize the generation of such waste through its recovery and recycling before being disposed of in landfill sites. For example, the collection rates of recyclable wastes in rural areas is 
expected to be at least once a month [30], even though, in most instances, these areas are often without the necessary infrastructure and logistical support.

Given the paucity of scientific literature in South Africa on rural municipal solid waste challenges, the main aim of this paper was to assess the status and effectiveness of waste management practices through an understanding of the opinions and perceptions of community residents within the rural local municipalities in Umkhanyakude and Zululand Municipal Districts, both located in the KwaZulu-Natal province of South Africa. Although such community feedback provides only one side of the performance indicators of this municipal waste management system, such information can yield key insights in locating operational barriers and challenges. The study also established the degree of willingness or unwillingness amongst community residents to pay for improved municipal waste management services, the extent of waste separation at source, and the benefits and barriers associated with their participation in recycling initiatives.

\section{Conceptual Framework and Literature Review}

\subsection{Contextualising Waste Management and Minimisation}

Municipal waste management involves the storage, collection, transportation, and final disposal of waste materials in landfill sites or by incineration; the prime purpose being to lessen the environmental impact of the pollution associated with these wastes and the decline of environmental quality [24]. However, South Africa has a history of poor waste management, including measures to reduce the quantity of waste streams [31]. Reducing waste quantities through minimisation is a source-oriented process and is traditionally comprised of measures such as waste recovery, reuse, and recycling [12,24] which warrant further elucidation in this paper because they are different.

Waste recycling is environmentally sustainable because it lessens the use of virgin natural resources and energy consumption while generating new products, employment opportunities, and incomes [24,31]. Also, recycling is broader than waste recovery and reuse because it represents an entire value chain which involves the direct collection, reclaiming (recovery) and reuse of waste materials such as paper, plastics, and glass either in their original form immediately after separation and cleaning or reprocessing [8]. To be more precise, waste recovery simply means that "resource materials (are) extracted from the waste stream with the intention to use as inputs into newer products" while reusing means "materials are used in a similar or different purpose without changing form or properties" [17,32,33].

For effective recycling, it is imperative that waste materials are sorted or separated first into various categories of recyclable and non-recyclable components prior to reuse or reprocessing [6]. Furthermore, waste segregation can take place at household level or at specialised sorting facilities and, therefore, proximity or distance to such facilities is an important factor that can encourage or retard public participation in recycling programs [34,35]. Internationally, waste separation at source and improved accessibility to buy-back facilities are important determinants and prerequisites for effective recycling programs $[10,34,36,37]$. Because of increasing quantities of municipal solid waste in many countries, including South Africa, there is a policy shift away from traditional types of waste management such as landfilling or incineration towards increased recycling trends $[16,31,38,39]$.

\subsection{Regulatory Framework for Municipal Solid Waste Management in South Africa}

As stated earlier, municipal solid waste management is a function carried out at municipal level in South Africa but the national and provincial governments have an important role to play as well [14]. Through the National Environmental Management: Waste Act [12], the national government is responsible for various roles including amongst others, providing the National Waste Management Strategy as well as setting norms and standards for handling different waste streams and supporting waste management services in different geographical areas. Some of the goals of the National Waste Management Strategy are to make sure that the provision of waste services is carried out effectively 
and efficiently, and that the local inhabitants are aware of the negative effects of waste on human health and environmental quality [15].

Apart from implementing the National Waste Management Strategy and ensuring compliance with the norms and standards, provinces must determine provincial waste information systems [15,39]. On the other hand, the supply of waste management services such as waste removal, temporary storage, and disposal services is the responsibility of municipalities in their various forms in South Africa [14]. While municipal solid waste is not the largest waste category in South Africa in terms of volume, it is very important in terms of the amount of public financial resources that are allocated to it and the environmental impacts it has on citizens [40]. Local population characteristics, social and economic factors, as well as geography play a key role to the extent that the financial standing of communities determines what kind of waste management service they would receive and what type and quantities of waste are generated [32]. Whereas accessibility to waste management services and collection rates are relatively high in the metropolitan municipalities ( $\sim 93 \%)$ and small towns $(\sim 74 \%)$, they are invariably lower in rural areas (16\%) [32]. Even so, waste recycling is weak in most rural areas, thanks to poor infrastructure and lack of institutional capacity, knowledge, and awareness on the part of community residents [14].

\subsection{Aspects of Municipal Waste Management and Recycling at Community Level}

Solid wastes generated from households in South Africa constitute a very important fraction (44\%) of total municipal solid waste [32]. However, most of the waste management research at household and community level in South Africa has focussed more on urban areas [23,25-27,41], thus many rural areas have been excluded. Ramukhwatho et al. [41,42] examined the generation and factors responsible for household food waste in some of the urban areas in the City of Tshwane Metropolitan Municipality in the Gauteng province of South Africa. Their studies revealed several factors responsible for the generation of food waste, but also indicated that up to $83 \%$ of their respondents relied on municipal collection service for household waste disposal, whereas only $3 \%$ of their respondents generated their own garden compost from the organic fraction of the waste [42]. Furthermore, Gumbi [27] characterised amongst other aspects, the status of household solid waste management and its recycling in the Ekurhuleni Metropolitan Municipality (EMM) of the Gauteng province. Her results indicated that $56 \%$ of households surveyed in the EMM received municipal waste collection service at least once a week meanwhile waste separation at source and some form of recycling were relatively low among the respondents, $5 \%$ and $24 \%$, respectively [27].

The aforementioned South African literature is pointing towards the lack of priority for an in-depth understanding on the status of rural municipal waste management services at household level and attendant recycling aspects. The scarcity of such research has led Van der Merwe and Steyl [29] to ask the most pertinent question: "what about waste generated in rural areas, especially in a country such as South Africa, where some $40 \%$ of the population still lives in rural settings?"

By contrast, even though the urban bias still exists in many countries, comparatively more is known internationally on the different aspects of municipal waste management and its recycling potential in predominantly rural areas $[17,19,43-45]$. Scientific knowledge that pertains to community satisfaction levels on current waste management systems, as well as their attitudes and willingness to recycle, is critical for improving the effectiveness of municipal solid waste management practices [44]. Factors attributed to weaknesses in some of the Chinese rural solid waste management systems included, amongst other barriers, institutional ineptness in executing waste management measures, lack of a suitable infrastructure and technical support, poor participation amongst community residents, and lack of relevant environmental knowledge and awareness levels [19,45]. In fact, if local inhabitants have more environmental knowledge and awareness levels on sustainable waste management practices, they are more likely to engage in pro-environmental behaviours $[19,46]$.

Furthermore, in a national survey conducted in Italy, it was demonstrated that, if households are conveniently provided with recycling bins, they are more likely to participate in recycling programmes 
for all materials [47]. During a study investigating capacity building in rural Guatemala, it was shown that one of the barriers hampering the widespread adoption of sustainable waste management schemes is the long distances traversed by recyclers and the high costs of transporting small volumes of recyclable material to buy-back centres [17]. This means that recycling, as a sustainable waste management option, will be practised more efficiently only if a closer recycling facility is built around communities in need of such infrastructure [17,47,48].

In view of the lack of comparable research findings in South Africa, and in the deep rural areas in particular, the need for evaluating the status of municipal solid waste management at household level and recycling potential is evident. Such research can provide important insights and critical success factors that local municipalities must understand before they can modify their waste management policies and practices for operational effectiveness.

\section{Materials and Methods}

\subsection{Study Area}

The geographical location of the study area is in the KwaZulu-Natal province of South Africa and is comprised of two district municipalities, namely, Umkhanyakude and Zululand (Figure 1). In terms of population size, KwaZulu-Natal is the second largest (11.1 million) province in South Africa after the Gauteng province (13.4 million) [49]. KwaZulu-Natal province has one metropolitan municipality, 10 district municipalities, collectively subdivided into 43 local municipalities [49]. Although, all district municipalities in the KwaZulu-Natal province have both urban and rural areas, both Umkhanyakude and Zululand District Municipalities are predominantly rural in their land use patterns [50] and were therefore suitable for the present research goal. Whereas Umkhanyakude District Municipality (UDM) has four local municipalities (Big 5 Hlabisa, Jozini, Mtubatuba, and Umhlabuyalingana), Zululand has five (Ulundi, Nongoma, Pongola, Abaqulusi, and Edumbe). Previous research conducted in these areas has mapped the location of illegal dumpsites, and has shown that the proportion of unpermitted disposal facilities is extremely high, with Zululand District Municipality (ZDM) having 83\% whilst UDM had $89 \%$ [50].

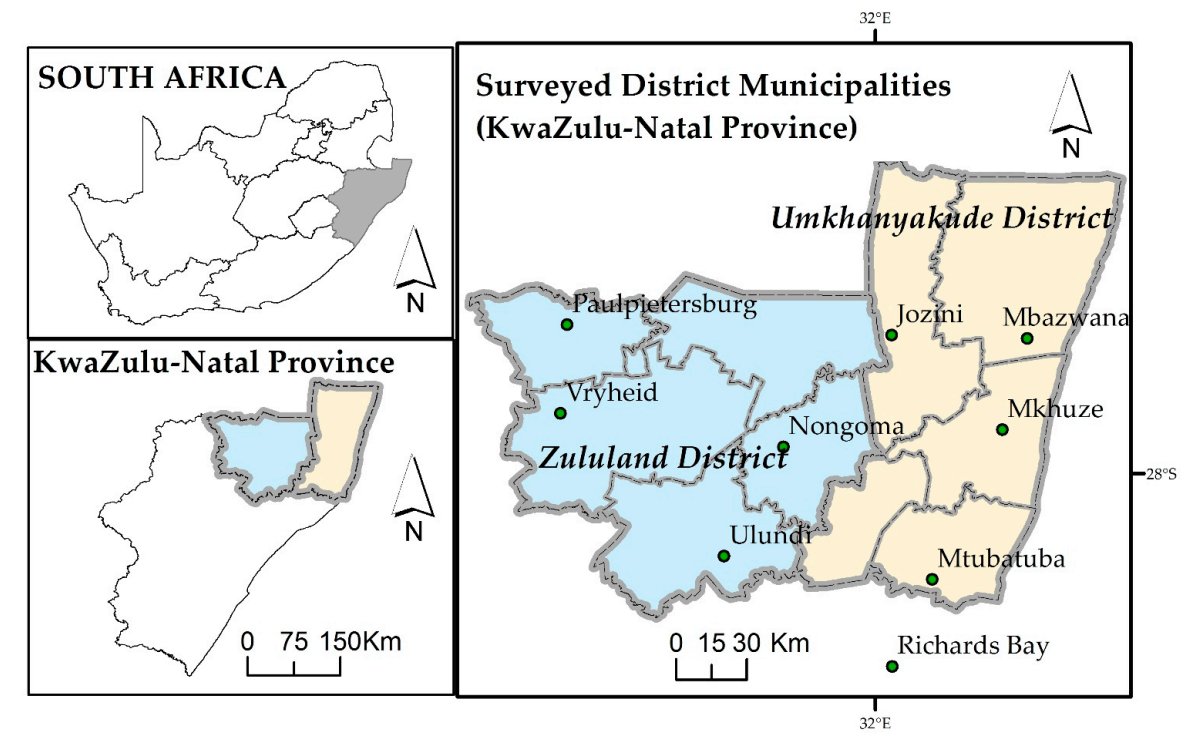

Figure 1. Map showing Umkhanyakude and Zululand District Municipalities in the KwaZulu-Natal province.

Similar under-resourced district municipalities such as Umkhanyakude and Zululand are found in other provinces in South Africa such as the Eastern Cape, Free State, Limpopo, North West, and the Northern Cape, and most of their rural areas have scattered or densely settled villages [51]. Most of 
these areas have a communal land tenure system and to a lesser or larger extent, they are under the jurisdiction of traditional tribal chieftaincies. Rural municipalities (B4) in these districts are invariably characterised by the highest number of backlogs in basic municipal services such as electricity, water, sanitation, and refuse removal [52].

\subsubsection{Geographical Characteristics of the Umkhanyakude District Municipality (UDM)}

The Umkhanyakude District Municipality (UDM) is located in the far northern region of the KwaZulu-Natal province and shares a border with Mozambique and Swaziland. This district has an area of approximately $13,855 \mathrm{~km}^{2}$ with a population totalling 625,846 and 128,195 households $[52,53]$. The UDM forms part of the Lubombo Trans-Frontier Conservation area and is the second largest district in KwaZulu-Natal in terms of size, behind the neighbouring Zululand District Municipality [53]. The UDM has a relatively small economy, contributing just $2.7 \%$ to the economy of the province [52]. The economic activities of the district are mainly concentrated in two economic (trade) sectors, namely, agriculture and tourism. These two sectors together contribute $55 \%$ of the total economy of this district [54]. However, educational and functional literacy levels as well as occupational skills levels are inherently very low [52]. Thus, the UDM is one of the poorest municipalities, not only in the KwaZulu-Natal province but also in South Africa [54]. Hence, it is one of the four district municipalities that are receiving presidential public funding from the Integrated Sustainable Rural Development Programme (ISRDP) in the province; the prime objectives being poverty alleviation, infrastructural development, as well as support for institutional and capacity development [52,54].

According to the 2014 Integrated Development Plan [53], waste management has been a challenge throughout the UDM, with poor solid waste disposal posing a threat to human health and environmental components such as freshwater resources and the quality of ambient air. The provision of regular refuse removal services is limited to larger residential centers within this district. Only $10 \%$ of households [53] were provided with weekly household refuse removal services compared to the overall provincial figure of 52\%. Furthermore, approximately 96,089 households in the same district made use of their own refuse dumps $(74 \%)$, with a further 15,989 households $(13 \%)$ that are without any form of rubbish disposal sites [53].

\subsubsection{Geographical Characteristics of the Zululand District Municipality (ZDM)}

The Zululand District Municipality (ZDM is also located in the far north of the KwaZulu-Natal province and borders Swaziland. This district has five local municipalities. In terms of governance, approximately $50 \%$ of the district area is allocated to traditional tribal authorities, while commercially owned farms and nature conservation areas constitute other important land-uses. The district covers an area of approximately $14,799 \mathrm{~km}^{2}$, with a population totalling 803,575 and has nearly 157,748 households [55]. The total percentage of urban households is only $25.4 \%$ while rural households make up $74.6 \%$ of the total population $[55,56]$. Given such a predominantly rural setting, this district is characterised by a high unemployment rate of $41 \%$, which is higher than the overall provincial rate of $28.5 \%$ [49,55]. The local municipalities of Uphongola, Ulundi and Nongoma have the highest unemployment rates compared to other local municipalities within the district [55]. However, the Abaqulusi Local Municipality has the highest number of households with employed inhabitants working predominantly in the agricultural farms within this area.

The most important towns are Vryheid and Ulundi, while Pongola and Paul Pietersburg constitute small service centres [55]. According to ZDM [56], economic investments in this district are generally small, thus not enough to enhance local economic development. Up to the late 1990s, the most important economic activity was coal mining, although its sphere of influence has declined markedly. During the 2011-2012 period, only 20\% of households in the ZDM received formal waste disposal support functions, and this was predominantly restricted to urban areas [56]. 


\subsection{Questionnaire Survey Design and Methods}

Scientific surveys entail finding relevant information on one or several groups relevant to the research problem and then asking pertinent questions on their characteristics regarding a phenomenon of interest [57]. Surveys are usually quantitative in nature and aim to give a broad overview of a representative sample of a large population [57,58]. Primary data required for such studies are collected by questionnaires and can be summarized by means of descriptive and inferential statistics. Several empirical studies which investigated the role and perceptions of different stakeholders in municipal solid waste management systems and associated recycling aspects have made use of both qualitative and quantitative surveys $[10,42,59]$. These surveys were undertaken by means of closedand open-ended questionnaires. There are also different means of undertaking household surveys: "telephone interviews, postal surveys, (and) web-based survey(s)" etc. [60].

In the present research, household surveys were undertaken by means of questionnaires that were administered during face-to-face interviews. These questionnaires had close-ended questions as well as Likert-type questions. Many studies on household waste management or recycling behavior have employed face-to-face questionnaire interviews mainly because of their high response rate although they can be expensive and time consuming [58-60]. For the present study area, each questionnaire was comprised of the following sections:

Section A: Demographic aspects (jurisdictions, gender, employment status, level of education, and waste management functions);

Section B: Aspects of waste management and recycling practices (including for example, municipal solid waste collection rates, collection of solid waste and recyclables, current recycling practices, waste separation practices at source, and storage of recyclables), as well as the barriers and benefits associated with waste recycling were included.

Additional primary data to supplement close-ended questions was obtained by means of open-ended questions which were asked during the latter part of interviews. The key outcomes of this data gathering activity were photographed by means of cell phone cameras (iPhone 6 and Samsung A3).

\subsection{Survey Procedures and Sampling Framework}

This study followed a random sampling approach, whereby households in the two study districts had an equal chance of being included in the survey. The interviews were targeting mainly heads of households and if not present, available adults were consulted. Thus, respondents aged 20 years and below were not involved in the interviews. The surveys began with a small pilot study (with $\sim 50$ interviews), of which the purpose was to establish the suitability of the questionnaires for data collection prior to the main surveys. The pilot testing also assessed the time taken by respondents to complete the questionnaires. This testing also determined the level of support sampled community residents would need to answer questions effectively, especially as illiteracy levels were very high in the study area. In fact, questions which dealt with technical aspects such as waste sorting or separation at source, waste reuse and waste recycling, and the differences between these terms, and the frequencies at which some services are provided were asked by means of the local native isiZulu language, and where respondents did not understand explanations were provided.

Another important aspect of survey procedures involved compliance with ethical considerations. To achieve such compliance, the purpose of the surveys was firstly explained to the respondents adequately, and interviews only proceeded when respondents provided prior informed consent to the interviewers. In this way, respondents were made aware that they were not compelled to participate in these interviews, and that at any stage they can withdraw without any adverse consequences for their wellbeing and welfare.

Out of 400 community households that were consulted in the various local municipalities during the data collection period (August and October 2015), 333 residents were successfully interviewed. Given one respondent per household, the total response rate was $83 \%$. Most of the respondents 
$(60.7 \% ; n=202)$ were from the Umkhanyakude District Municipality whilst $39.3 \%(n=131)$ of them were from Zululand. This discrepancy in the proportions of respondents interviewed per district municipality did not distort the results because all households are provided with the same municipal waste management services.

\subsection{Statistical Data Processing and Analysis}

The validity and reliability of the investigations was undertaken by using Cronbach's alpha to verify whether the questionnaires were credible and internally consistent. The general agreed lower limit that was used was 0.7 , while 0.6 was used as an acceptable level in the case where agreed lower limit of 0.7 could not be achieved. The reliability of questionnaires is depicted in Table 1 . All the major aspects or sections of the questionnaire met the minimum agreed level of 0.7 , as proposed by Revelle and Zinbarg [61]. The reliability of the overall instrument was found to be 0.824 .

Table 1. The reliability of aspects in the questionnaires for community residents.

\begin{tabular}{cccc}
\hline Aspect & No of Items & Cronbach's Alpha & Acceptable Level \\
\hline Benefits from recycling and waste minimization operations & 7 & 0.803 & Good \\
Barriers to recycling and waste minimization & 16 & 0.932 & Excellent \\
Aspects assisting the community in waste minimisation and recycling & 9 & 0.963 & Excellent \\
Total & 32 & 0.824 & Good \\
\hline
\end{tabular}

The primary data obtained from responses provided by interviewed community residents were processed into the Microsoft Excel (2010) programme and statistical analyses were carried out by means of SPSS version 24. Descriptive statistics in the form of tables, frequencies, and percentages were used to describe the patterns and trends in the data set.

\section{Results and Discussion}

\subsection{Characteristics of Respondents}

Table 2 summarises the demographic characteristics of respondents. Out of the 333 community residents that were interviewed, $60.7 \%(n=202)$ of them were women, while $39.3 \%(n=131)$ were men. This gender distribution is in line with the population characteristics in the study area as women have in many instances (i.e., 1996, 2001, and 2011 Census) accounted for approximately $54 \%$ of the local inhabitants $[52,54,55]$. Part of this population imbalance is also attributable to the temporary migration of men aged 25-29 years to fast growing urban areas in search of employment opportunities [54,55].

The proportion of educational achievements below a senior high school (matric) qualification amongst the respondents was comparatively large $(n=134,40.2 \%)$ relative to those who have obtained a matric certificate $(n=105,31.5 \%)$ (Table 2). On the other hand, those without any educational background constituted $16.5 \%(n=55)$ of the whole sample meanwhile a college qualification $(n=24,7.2 \%)$ and a university degree certificate $(n=15,4.5 \%)$ was reported for only a few respondents. Educational levels in the districts surveyed have always been low relative to levels prevailing in the KwaZulu-Natal province. According to the Institute of Natural Resources [52], the percentages of local inhabitants with a secondary school qualification $(16.8 \%)$ or tertiary education $(0.5 \%)$ were extremely low for the Umkhanyakude District Municipality. Furthermore, the population over the age of 20 years without any schooling background in the same district ranged from $23 \%$ amongst men to $27 \%$ amongst women whereas the provincial statistic was relatively less (8-13\%), respectively [54]. 
Table 2. Demographic characteristics of respondents $(n=333)$.

\begin{tabular}{cccc}
\hline Variable & Category & $\mathbf{F}$ & $\%$ \\
\hline District Municipality & Umkhanyakude & 202 & $60.7 \%$ \\
District Municipality & Zululand & 131 & $39.3 \%$ \\
& Total & 333 & $100.0 \%$ \\
\hline Gender & Male & 131 & $39.3 \%$ \\
& Female & 202 & $60.7 \%$ \\
& Total & 333 & $100.0 \%$ \\
\hline Employment Status & Employed & 101 & $30.5 \%$ \\
& Self-employed & 140 & $42.3 \%$ \\
& Unemployed & 90 & $27.2 \%$ \\
& Total & 331 & $100.0 \%$ \\
\hline Income & Not more than R500 (39.1 USD) & 51 & $20.1 \%$ \\
& R501 to R1000 (39.2-78.3 USD) & 94 & $37.0 \%$ \\
& R1001 to R1500 (78.3-117.5 USD) & 48 & $18.9 \%$ \\
& R1501 to R5000 (117.5-391.5 USD) & 32 & $12.6 \%$ \\
& R5001 to R10,000 (391.6-783.1 USD) & 16 & $6.3 \%$ \\
More than R10,000 (783.1 USD) & 13 & $5.1 \%$ \\
& Total & 254 & $100 \%$ \\
\hline Level of Education & No Education at all & 55 & $16.5 \%$ \\
& Under Grade 12 Matriculation & 134 & $40.2 \%$ \\
& Matric Certificate & 105 & $31.5 \%$ \\
& College Diploma & 24 & $7.2 \%$ \\
& University Degree & 15 & $4.5 \%$ \\
& Total & $100.0 \%$ \\
\hline
\end{tabular}

Regarding employment patterns (Table 2), those who were formally employed amounted to $30.5 \%$ $(n=101)$ and those who were self-employed constituted $42.3 \%(n=140)$. An unemployment level amongst the respondents was found to be $27.2 \%(n=90)$, which is lower than the $41 \%$ average reported for both district municipalities $[49,62,63]$.

Most $(n=94,37 \%)$ of the respondents reported an individual monthly income level of R501-R1000 (i.e., 39.2-78.3 USD) whereas $20.1 \%(n=51)$ of them had a monthly income of less than R500 (39.1 USD). Compared to national monthly incomes, the R501-R1000 (i.e., 39.2-78.3 USD) category corresponds well with the R570 (44 USD) and R845 (65 USD) earned by the bottom 5\% and 10\% of the economically active part of the South African population, respectively [64]. Respondents who earned R1001-R1500 (78.3-117.5 USD) per month in the present survey amounted to $18.9 \%(n=48)$ while R1501-R5000 (117.5-391.5 USD) earnings were reported by $12.6 \%(n=32)$ of the respondents. By contrast, higher individual monthly incomes were received by very few respondents in this survey. For example, only 5.1\% $(n=13)$ of respondents earned more than R10,000 (783.1 USD) per month. Even if average household income levels for Umkhanyakude and Zululand District Municipalities have increased by over 100\% during the 2001-2011 period, they are still below levels reported for the KwaZulu-Natal province. For example, households in the Zululand District Municipality had an average monthly income of R2062 (158 USD) in 2001 which increased to R4450 (342 USD) in 2011. Be that as it may, this increase falls below the provincial average income levels (i.e., R3242 or 249 USD in 2001 and the R6920 or 532 USD in 2011) for the same period [64].

\subsection{Provision of Waste Management Services}

Based on Figure 2, most of the respondents expressed negative opinions and perceptions regarding the extent to which local municipalities provide certain waste management services. For example, services such as creating environmental awareness amongst community residents $(n=319,95.8 \%)$, collection of recyclable materials from domestic premises $(n=229,68.7 \%)$, or solid wastes from informal (i.e., illegal) waste dumps $(n=250,75 \%)$ are not being adequately provided in the surveyed districts. Similarly, garden waste from domestic premises $(n=319,95.8 \%)$ is also not collected by local municipalities. On the other hand, local municipalities were found to be responsible for the 
collection of domestic solid wastes $(n=222,66.7 \%)$ from households as well as the management of landfill operations $(n=137,41 \%)$.

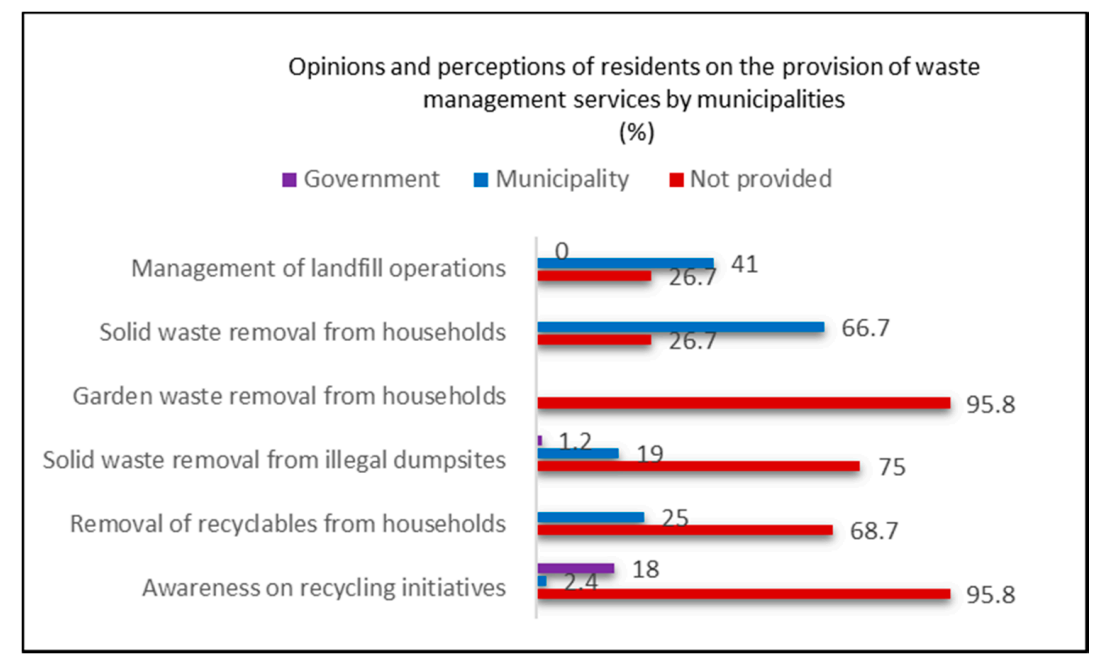

Figure 2. Resident's opinions and perceptions on provided waste management services.

\subsection{Satisfaction Levels on the Effectiveness of Municipal Waste Collection}

Satisfaction levels for municipal waste collection services amongst the respondents are depicted in Table 3. Although $70.3 \%(n=234)$ of respondents mentioned that local municipalities do collect solid wastes from their homes, the degree of dissatisfaction on the effectiveness of services rendered was markedly high $(n=324,97.3 \%)$. Approximately $49.1 \%(n=164)$ of respondents mentioned that municipal solid waste is collected at least once a week, while $31.3 \%(n=104)$ indicated that it is never collected.

Table 3. Satisfaction levels on municipal waste collection services.

\begin{tabular}{|c|c|c|}
\hline \multirow{2}{*}{ Statement } & \multicolumn{2}{|c|}{ Responses } \\
\hline & Yes & No \\
\hline Do the municipality collect solid waste from your households? & $\begin{array}{c}70.3 \% \\
(234)\end{array}$ & $\begin{array}{c}29.7 \% \\
(99)\end{array}$ \\
\hline Does the municipality collect solid wastes at least once a week from households? & $\begin{array}{c}49.1 \% \\
164 \\
\end{array}$ & $\begin{array}{r}50.9 \% \\
(169) \\
\end{array}$ \\
\hline Is domestic solid waste never collected from your households? & $\begin{array}{c}31.3 \% \\
(104)\end{array}$ & $\begin{array}{r}68.7 \% \\
(229) \\
\end{array}$ \\
\hline Are you willing to pay for waste collection services rendered? & $\begin{array}{c}6.9 \% \\
(23)\end{array}$ & $\begin{array}{r}93.1 \% \\
(310)\end{array}$ \\
\hline Are you satisfied with service collection rendered in your area? & $\begin{array}{c}2.7 \% \\
(9)\end{array}$ & $\begin{array}{r}97.3 \% \\
(324)\end{array}$ \\
\hline Does uncollected waste cause environmental problems in open spaces and neighbourhoods? & $\begin{array}{l}83 \% \\
(276)\end{array}$ & $\begin{array}{l}17 \% \\
(57)\end{array}$ \\
\hline
\end{tabular}

A major concern $(n=276,83 \%)$ expressed by respondents was related to the poor quality of services rendered by municipalities and the attendant environmental problems that are caused by decaying wastes not only in the vicinity of their households but also in and around open spaces (Figure 3). Hence, when respondents were asked about their willingness to pay for municipal waste management services they receive, the majority $(n=310,93.1 \%)$ of them expressed negative perceptions towards such payments. This unwillingness to pay may also be attributed to the ambiguous manner in which the national policy of free basic services is accorded to indigent households. This policy should 
cater only for households that live below the poverty line which has increased from R335 (26 USD) per person per month in 2011 to approximately R498 (30 USD) in 2016 [64] However, the distinction between households that are entitled to free basic services and households which can actually afford to pay for such services is not always clear cut in South African municipalities, thereby resulting in less revenue collection for affected municipalities.

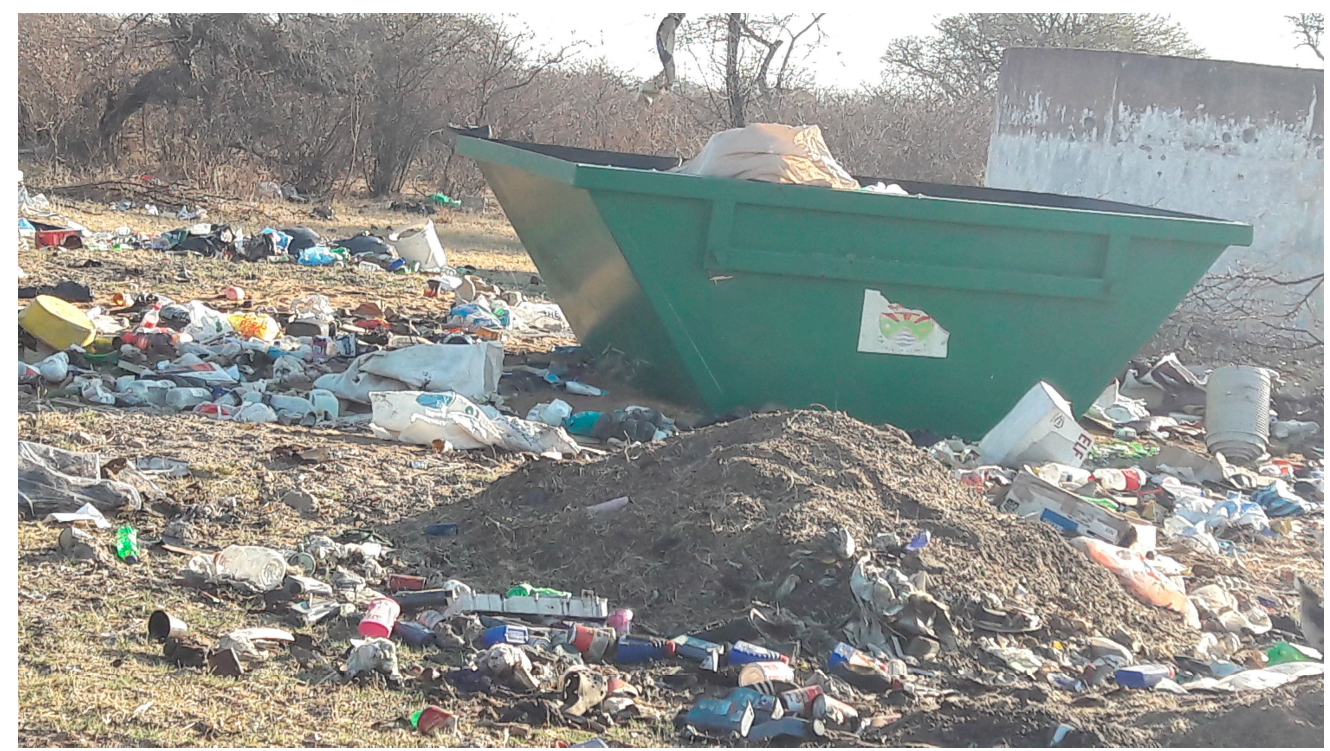

Figure 3. Poor waste collection within communities and attendant environmental despoliation.

\subsection{Willingness to Participate in Waste Separation at Source and Recycling}

The willingness of respondents towards waste recycling and separation at source is depicted in Table 4. The survey found that $98 \%(n=326)$ of respondents were not involved in any waste recovery initiatives in their neighbourhoods. However, when given an opportunity to do so, $51.4 \%$ $(n=171)$ of them were willing to participate in such initiatives (Table 4). Although waste segregation is an important prerequisite towards effective recovery and subsequent recycling, a large proportion ( $n=321,96.7 \%$ ) of respondents were ignorant regarding the process of waste sorting prior to collection by municipalities or buy-back centres. Similar findings have been reported by Taghipour et al. [65] in Iran whereby routine household waste separation is not systematically applied in some of their rural villages. However, the practices of community residents in the Umkhanyakude and Zululand District Municipalities differed markedly with findings reported by Bernardes and Günther [43] in Brazil, where waste separation amongst some of their rural villages was successfully executed.

Table 4. Willingness and knowledge on waste separation at source.

\begin{tabular}{ccc}
\hline \multirow{2}{*}{ Statement } & \multicolumn{2}{c}{ Response } \\
\cline { 2 - 3 } & Yes & No \\
\hline Are you involved in local recycling initiatives? & $98 \%$ & $2 \%$ \\
& $(326)$ & $(7)$ \\
\hline \multirow{2}{*}{ Do you separate waste at source? } & $2.4 \%$ & $97.6 \%$ \\
& $(8)$ & $(324)$ \\
\hline \multirow{2}{*}{ Do you have any knowledge about waste separation at source? } & $3.3 \%$ & $96.7 \%$ \\
& $(11)$ & $(321)$ \\
\hline \multirow{2}{*}{ Given the new knowledge on waste separation, are you willing to sort waste? } & $38.6 \%$ & $61.4 \%$ \\
& $(128)$ & $(204)$ \\
\hline \multirow{2}{*}{ Do the residents separate waste at source in your area? } & $14.2 \%$ & $85.8 \%$ \\
& $(47)$ & $(285)$ \\
\hline
\end{tabular}


On the other hand, when the process of waste segregation was explained to respondents during interviews in the Umkhanyakude and Zululand District Municipalities, only 38.6\% $(n=128)$ of them were willing to become involved. They also indicated that their local municipalities do not have regular and sustained projects $(76.6 \%)$ on waste separation at source. Undertaking waste separation is also unattainable due to the lack of different containers in their households for enabling waste segregation $(n=330,99.0 \%)$ at source. As for the small minority $(n=2,2 \%)$ of respondents who were already involved in some form of waste recovery, the absence of financial incentives for reduced loads for municipal collection was another major concern. To make the situation worse, some of the recovered wastes that were sourced from different households and from elsewhere in their neighbourhoods have simply accumulated in their yards (Figure 4) without any collection either by municipalities or representatives of buy-back centres.

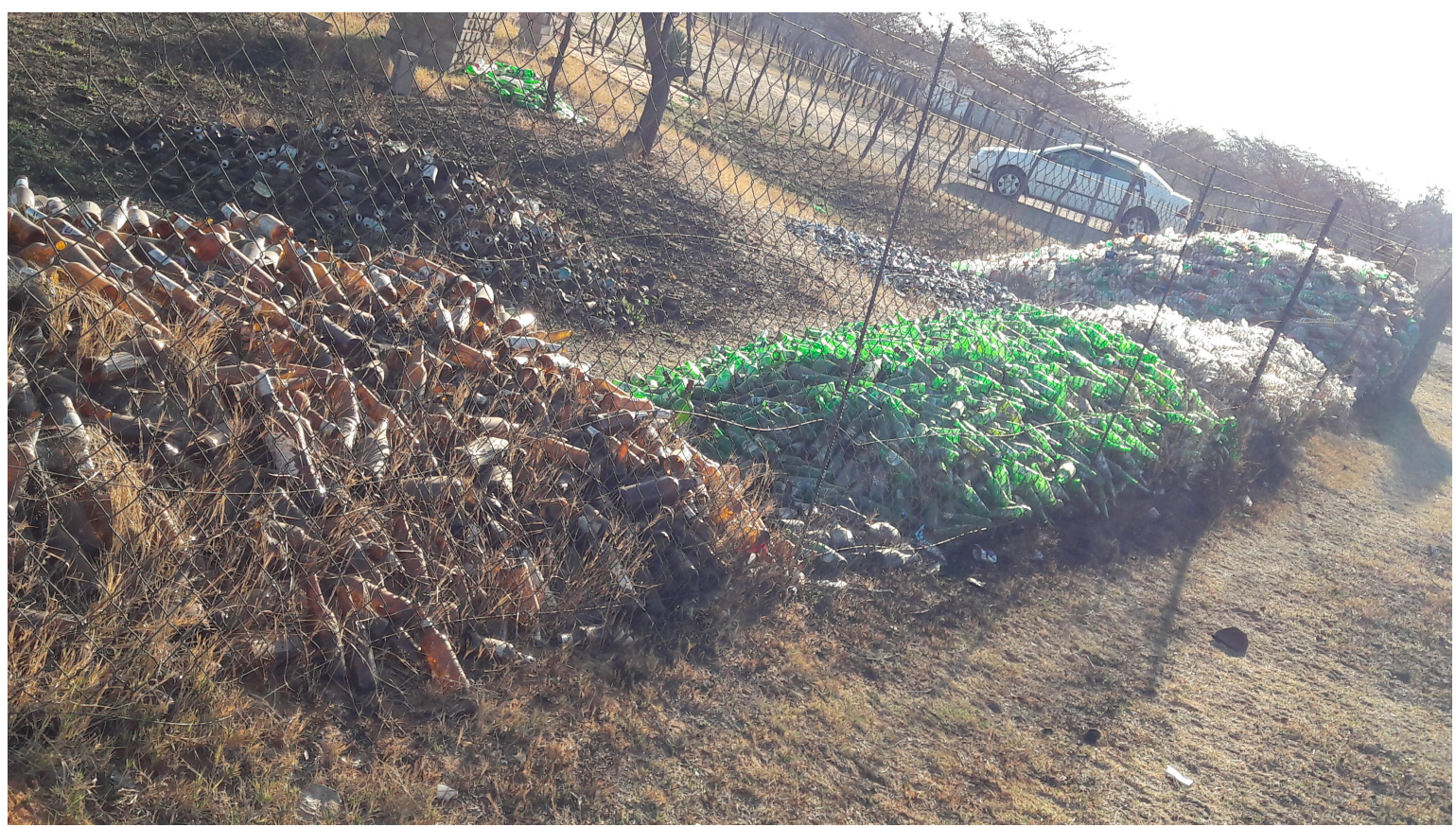

Figure 4. Uncollected sorted waste left for many months in a yard.

\subsection{Respondents' Opinions and Perceptions on Benefits to Increased Recycling and Waste Minimization Operations}

Despite very low recycling rates prevailing in the districts surveyed, some of the respondents could associate certain benefits with increased solid waste material recovery (Table 5). These benefits included the creation of jobs and the potential for income generation from selling recyclable materials to the buy-back centers. To a large degree $(n=142,42.8 \%)$ and to a very large extent $(n=113,34.0 \%)$, the possibility of new jobs was regarded as one of the most important advantage that can be realized from waste recycling, and was followed by the potential to earn extra money through the selling ( $n=115,34.7 \%)$ of recyclable waste items. Such high percentages for income generation potential are reflective of the general lack of employment opportunities in the districts surveyed.

Nearly ten years ago, a study conducted in a low-income urban area of Cape Town indicated that informal waste pickers or so-called scavengers can earn up to R400 (31 USD) per month from selling different recyclable waste items [25]. In the Umkhanyakude and Zululand District Municipalities, respondents who could link increased recycling rates with clean streets $(n=89,26.98 \%)$ and improved sanitation in their neighborhoods $(n=92,27.8 \%)$ were nearly equal in terms of the proportions involved. To some extent, respondents also hoped to gain from the development of recycling infrastructure ( $n=138,41.7 \%$ ) should municipalities make such investments in the future. 
Table 5. Anticipated benefits of recycling municipal and household wastes.

\begin{tabular}{|c|c|c|c|c|c|c|}
\hline \multirow[b]{2}{*}{ Statement } & \multicolumn{5}{|c|}{ Level of Extent } & \multirow[b]{2}{*}{ Mean } \\
\hline & $\begin{array}{c}\text { To a Very } \\
\text { Large Extent }\end{array}$ & $\begin{array}{l}\text { To a Large } \\
\text { Extent }\end{array}$ & $\begin{array}{l}\text { To Some } \\
\text { Extent }\end{array}$ & $\begin{array}{l}\text { To a Little } \\
\text { Extent }\end{array}$ & $\begin{array}{l}\text { No to Any } \\
\text { Extent at All }\end{array}$ & \\
\hline Creation of jobs & $\begin{array}{l}34.0 \% \\
(113)\end{array}$ & $\begin{array}{l}42.8 \% \\
(142)\end{array}$ & $\begin{array}{c}22.3 \% \\
(74)\end{array}$ & $\begin{array}{c}0.3 \% \\
(1)\end{array}$ & $\begin{array}{c}0.6 \% \\
(2)\end{array}$ & 4.09 \\
\hline Potential for earning extra money & $\begin{array}{c}11.8 \% \\
(39)\end{array}$ & $\begin{array}{l}34.7 \% \\
(115)\end{array}$ & $\begin{array}{l}34.4 \% \\
(114)\end{array}$ & $\begin{array}{c}16.3 \% \\
(54)\end{array}$ & $\begin{array}{l}2.7 \% \\
(9)\end{array}$ & 3.37 \\
\hline $\begin{array}{l}\text { Improved sanitation and } \\
\text { clean environment }\end{array}$ & $\begin{array}{l}1.2 \% \\
(4)\end{array}$ & $\begin{array}{c}27.8 \% \\
(92)\end{array}$ & $\begin{array}{l}42.0 \% \\
(139)\end{array}$ & $\begin{array}{l}25.7 \% \\
(85)\end{array}$ & $\begin{array}{c}3.3 \% \\
(11)\end{array}$ & 2.98 \\
\hline Street/town cleaning & $\begin{array}{l}0.9 \% \\
(3) \\
\end{array}$ & $\begin{array}{c}26.9 \% \\
(89)\end{array}$ & $\begin{array}{l}42.9 \% \\
(142) \\
\end{array}$ & $\begin{array}{c}26.0 \% \\
(86) \\
\end{array}$ & $\begin{array}{c}3.3 \% \\
(11) \\
\end{array}$ & 2.96 \\
\hline Capacity building/training & $\begin{array}{c}0.9 \% \\
(3)\end{array}$ & $\begin{array}{l}28.4 \% \\
(94)\end{array}$ & $\begin{array}{l}40.5 \% \\
(134)\end{array}$ & $\begin{array}{c}25.7 \% \\
(85)\end{array}$ & $\begin{array}{l}4.5 \% \\
(15)\end{array}$ & 2.95 \\
\hline Infrastructure development & $\begin{array}{c}1.2 \% \\
(4)\end{array}$ & $\begin{array}{c}25.1 \% \\
(83)\end{array}$ & $\begin{array}{l}41.7 \% \\
(138)\end{array}$ & $\begin{array}{c}26.3 \% \\
(87)\end{array}$ & $\begin{array}{l}5.7 \% \\
(19)\end{array}$ & 2.9 \\
\hline
\end{tabular}

Furthermore, if the local municipalities can introduce capacity building schemes, close to $40.5 \%$ $(n=134)$ of the respondents hope that they will acquire relevant knowledge and skills transfers which can better position them for meaningful participation in the waste recycling sector. A similar approach delivered very positive outcomes in the rural villages of Guatemala, when a short course and associated training on practical skills equipped interested community residents with knowledge on the fundamental principles of municipal solid waste management and its recycling potential [17].

\subsection{Respondents' Opinions and Perceptions on Barriers to Increased Recycling and Waste Minimization Operations}

Table 6 provides a summary on barriers that constrain solid waste recycling practices in the study area. To a large extent, the lack of support from the national and provincial governments $(n=178$, $53.6 \%)$, as well as local municipalities $(n=190,56.9 \%)$ was regarded by respondents as an important constraint against effective solid waste recycling. Similarly, without appropriate working space and facilities for communal recycling operations $(n=178,53.6 \%)$, it is difficult for households to adopt recycling practices. In fact, respondents were concerned that the lack of dedicated space for putting their waste items inevitably leads to a situation where $(n=100,30.1 \%)$ recyclers have to burn their excess recyclable materials; otherwise, they have no free space to store other recyclable materials. This is an unsustainable practice that they have seen amongst informal waste collectors or so called scavengers in their communities and in the landfill sites. Again, operating without adequate shelter ( $n=178,53.6 \%)$ against weather elements and financial support $(n=160,48.2 \%)$ was perceived to a large extent to be a significant barrier that discourages potential waste recyclers. Poor accessibility to recycling markets $(n=126,38.0 \%)$ implies no opportunities for selling recovered waste items. This means that such wastes will remain unsold and unused for several months, thus causing aesthetic and other environmental problems for community residents.

The barriers highlighted by respondents in the present survey have also been mentioned in the urban areas of South Africa [23,26,27]. For instance, both Bhagwandin [66] and Gumbi [27] have mentioned the lack of funding opportunities and a supporting infrastructure needed for enhancing domestic and municipal recycling programmes in certain local municipalities of the Gauteng province. To circumvent and reduce the negative impact of these barriers, local governments have a crucial role to play in creating an enabling framework for sustainable solid waste recycling practices [67]. 
Table 6. Barriers that constrain solid waste recycling practices.

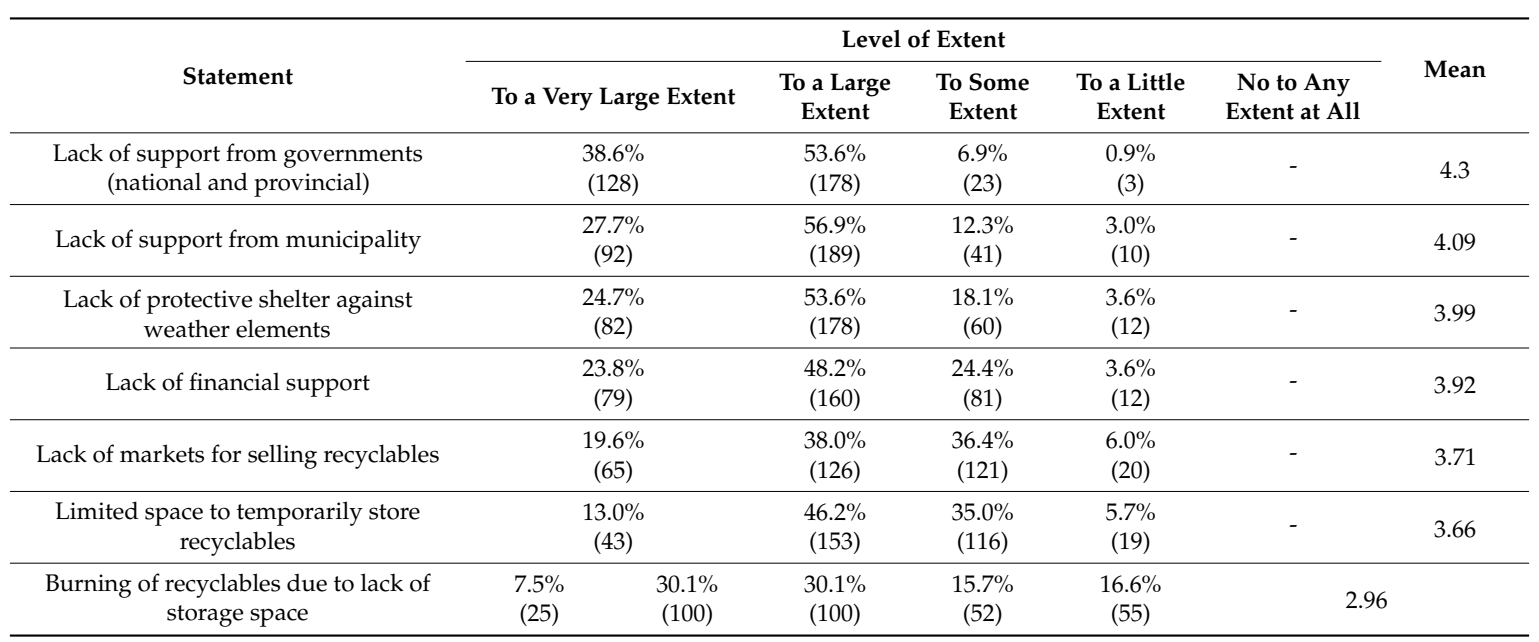

\section{Conclusions and Recommendations}

In this survey, the current situation and effectiveness of waste management practices as well as the potential for increased waste recycling efforts in the rural areas of Umkhanyakude and Zululand District Municipalities in the KwaZulu-Natal province of South Africa has been assessed. This assessment was conducted from the viewpoint of community resident's opinions and perceptions, making it one of the few baseline researches in the South African rural landscape. Given deficient educational backgrounds, high unemployment rates and meagre incomes amongst the respondents, especially in the light of recurrent economic recessions, it is difficult for inhabitants to cater for their own living expenses and household needs, let alone paying for municipal waste management services. Inevitably, there are high levels of dissatisfaction with local municipalities because more is expected from these institutions in terms of providing basic services, including regular waste collections and improved sanitation in the neighbourhoods. Another important constraint against effective waste management lies in the application of the free basic services policy that is earmarked for poor or indigent households in South Africa. The main problem with the implementation of this policy, not only in the studied district municipalities but everywhere in the low-income residential areas of South Africa, is the lack of criteria for differentiating between households that must be exempted from paying for waste management services and those that must pay even if set at a reduced nominal fee.

Progress towards integrated waste management is very limited in the surveyed areas because municipalities are more preoccupied with the need to increase the accessibility of waste management services to under-serviced rural communities rather than investing in the infrastructure for successful waste recycling programmes. This state of affairs is clearly defined in the various integrated development plans of these district municipalities, which seem to prioritize the need to address service backlogs without establishing institutional arrangements for increased waste recycling in the affected rural areas [54,55]. It is therefore not surprising to find a large proportion $(96.7 \%)$ of respondents who are without relevant knowledge on how waste recycling can be practised at household level, along with the lack of waste sorting facilities or buy-back centres in close proximity to their homes. Inevitably, communities are expecting increased waste collection rates from the municipalities and very little towards the adoption of waste recycling and all the related mechanisms (i.e., waste separation, recovery, sorting, and reuse) that accompany its implementation.

As long as this status quo remains in these districts and there are no facilities for waste separation, the mixing of household solid wastes will continue unabated and recyclable waste will continue to be directed towards landfill sites for final disposal, thus undermining long term environmental sustainability. 
Given the challenges local municipalities and residents are facing in the district municipalities surveyed, a number of recommendations are made. Firstly, there is a need for increased environmental awareness programmes at the district and municipal level so that residents acquire relevant knowledge for pro-environmental behaviour. As pointed out by Vicente and Reis [68] "citizens who are better informed about recycling have a greater propensity to participate in recycling than those who are not so well informed". Also, in several studies, it has been established that the supply of waste segregation and storage facilities are positively linked to increased community participation rates in recycling programs [10,67-70]. Secondly, research on the composition and volumes of municipal solid waste is recommended along with determining amounts of recyclable wastes from the municipal waste streams.

Acknowledgments: We are thankful for the permission provided for undertaking this survey in the various communities located in the Umkhanyakude and Zululand District Municipalities in the KwaZulu-Natal province of South Africa. The primary data for this paper were collected as a part of a research project conducted by Bonginkosi Robert Dlamini for a PhD Environmental Management degree programme at the University of Johannesburg. All the authors wish to express their sincere appreciation and thanks for the prior informed consent that was given by each respondent prior to questionnaire-administered interviews.

Author Contributions: All the authors have contributed in the conceptual research design and writing of this manuscript. Bonginkosi Robert Dlamini conducted the primary data collection, analyses and preliminary drafting of the research article. Isaac Tebogo Rampedi supervised the whole research process, including data collection and analyses, and writing of the manuscript. Ayodeji Peter Ifegbesan has read the entire manuscript for critical commentary and contributed in statistical analyses.

Conflicts of Interest: The authors declare no conflicts of interest.

\section{References}

1. Fehr, M.; de Castro, M.S.M.V.; Calcado, M.D.R. A practical solution to the problem of household waste management in Brazil. Resour. Conserv. Recycl. 2000, 30, 245-257. [CrossRef]

2. Henry, R.K.; Yongsheng, Z.; Jun, D. Municipal solid waste management challenges in developing countries-Kenyan case study. Waste Manag. 2006, 26, 92-100. [CrossRef] [PubMed]

3. Zhang, D.Q.; Tan, S.K.; Gersberg, R.M. Municipal solid waste management in China: Status, problems and challenges. J. Environ. Manag. 2010, 9, 1623-1633. [CrossRef] [PubMed]

4. Nandy, B.; Sharma, G.; Garg, S.; Kumari, S.; George, T.; Sunanda, Y.; Sinha, B. Recovery of consumer waste in India-A mass flow analysis for paper, plastic and glass and the contribution of households and the informal sector. Resour. Conserv. Recycl. 2015, 101, 167-181. [CrossRef]

5. Taherymoosavi, S.; Verheyen, V.; Munroe, P.; Joseph, S.; Reynolds, A. Characterization of organic compounds in biochars derived from municipal solid waste. Waste Manag. 2016, 67, 131-142. [CrossRef] [PubMed]

6. Hong, J.; Chen, Y.; Wang, M.; Ye, L.; Qi, C.; Yuan, H.; Zheng, T.; Li, X. Intensification of municipal solid waste disposal in China. Renewv. Sustain. Energy Rev. 2017, 69, 168-176. [CrossRef]

7. Sudibyo, H.; Majid, A.I.; Pradana, Y.S.; Budhijanto, W.; Budiman, A. technological evaluation of municipal solid waste management system in Indonesia. Energy Procedia 2017, 105, 263-269. [CrossRef]

8. Porteous, A. Dictionary of Environmental Science and Technology, 3rd ed.; John Wiley \& Sons: New York, NY, USA, 2000.

9. World Bank. Waste Management in China: Issues and Recommendations; Urban Development Working Papers 9; East Asia Infrastructure Department: Washington, DC, USA, 2005.

10. Asim, M.; Batool, S.A.; Chaudhry, M.N. Scavengers and their role in the recycling of waste in Southwestern Lahore. Resour. Conserv. Recycl. 2012, 58, 152-162. [CrossRef]

11. US Environmental Protection Agency (USEPA). Municipal Solid Waste. 2017. Available online: https: //archive.epa.gov/epawaste/nonhaz/municipal/web/html/ (accessed on 31 August 2017).

12. South Africa (SA). National Environmental Management: Waste Act; Act No. 59 of 2008; South African Government Gazette: Pretoria, South Africa, 2008.

13. Matete, N.; Trois, C. Towards zero waste in emerging countries-A South African experience. Waste Manag. 2008, 28, 1480-1492. [CrossRef] [PubMed] 
14. Department of Environmental Affairs. South Africa Environmental Outlook: Chapter 9: Waste Management. 2012. Available online: www.http/:dea.gov.za (accessed on 31 August 2017).

15. Department of Environmental Affairs. National Waste Management Strategy. 2011. Available online: https: / / www.environment.gov.za/sites/default/files/docs/nationalwaste_management_strategy.pdf/ (accessed on 30 August 2017).

16. Troschinetz, A.M.; Mihelcic, J.R. Sustainable recycling of municipal solid waste in developing countries. Waste Manag. 2009, 29, 915-923. [CrossRef] [PubMed]

17. Zarate, M.A.; Slotnick, J.; Ramos, M. Capacity building in rural Guatemala by implementing a solid waste management program. Waste Manag. 2008, 28, 2542-2551. [CrossRef] [PubMed]

18. Obeng, P.A. Assessment of institutional structures for solid waste management in Kumasi. Water and Sanitation Group, Department of Chemistry, University of Cape Coast, Ghana. Manag. Environ. Qual. Int. J. 2009, 20, 106-120. [CrossRef]

19. He, P. Municipal solid waste in rural areas of developing country: Do we need special treatment mode? Waste Manag. 2012, 32, 1289-1290. [CrossRef] [PubMed]

20. Department of Environmental Affairs (DEA). National Policy for the Provision of Basic Refuse Removal Services to Indigent Households. 2010. Available online: www.dea.gov.za/ (accessed on 31 August 2017).

21. South Africa. Constitution of the Republic of South Africa Constitution; South African Government Gazette: Pretoria, South Africa, 1996.

22. South Africa. Local Government: Municipal Systems Act; Act No. 32 of 2000; South African Government Gazette: Pretoria, South Africa, 2000.

23. Ginindza, B.; Muzenda, E. Community Perspectives on Waste Management and Minimisation: A Case Study for Mogale City and Westonaria Municipalities. In Proceedings of the International Conference on Integrated Waste Management and Green Energy Engineering, Johannesburg, South Africa, 15-16 April 2013.

24. Bosman, C. Integrated waste management. In Fuggle and Rabie's Environmental Management in South Africa, 2nd ed.; Strydom, H.A., King, N.D., Eds.; Juta: Cape Town, South Africa, 2012.

25. Langenhoven, B.; Dyssel, M. The recycling industry and subsistence waste collectors: A case study of Mitchell's plain. Urban Forum 2007, 18, 114-132. [CrossRef]

26. Schenck, R.; Blaauw, P.F. The work and lives of street waste pickers in Pretoria-A case study of recycling in South Africa's urban informal economy. Urban Forum 2011, 22, 411. [CrossRef]

27. Gumbi, S.E. Current Waste Management and Minimisation Patterns and Practices: An Exploratory Study in the Ekurhuleni Metropolitan municipality in South Africa. Master's Dissertation, University of South Africa, Pretoria, South Africa, 2015.

28. Gopaul, M. The Significance of Rural Areas in South Africa for Tourism Development through Community Participation with Special Reference to Umgababa, a Rural Area Located in the Province of KwaZulu-Natal. Master's Thesis, University of Pretoria, Pretoria, South Africa, 2006.

29. Van der Merwe, H.; Steyl, I. Solid waste management in intensively farmed rural areas: A Western Cape case study. Acta Acad. 2005, 37, 184-211.

30. Department of Environmental Affairs and Tourism (DEAT). Assessment of the Status of Waste Service Delivery and Capacity at Local Government Level; Department of Environmental Affairs and Tourism: Pretoria, South Africa, 2007.

31. Nahman, A.; Godfrey, L. Economic instruments for solid waste management in South Africa: Opportunities and constraints. Resour. Conserv. Recycl. 2010, 54, 521-531. [CrossRef]

32. Department of Environmental Affairs. National Waste Information Baseline Report; Department of Environmental Affairs: Pretoria, South Africa, 2012.

33. Moh, L.; Manaf, A.B.D. Solid waste management transformation and future challenges of source separation and recycling practice in Malaysia. Resour. Conserv. Recycl. 2017, 116, 1-14. [CrossRef]

34. Czajkowski, M.; Kadziela, T.; Hanley, N. We want to sort! Assessing households' preferences for sorting waste. Resour. Energy Econ. 2014, 36, 290-306. [CrossRef]

35. Struk, M. Distance and incentives matter: The separation of recyclable municipal waste. Resour. Conserv. Recycl. 2017, 122, 155-162. [CrossRef]

36. Matsumoto, S. Waste separation at home: Are Japanese municipal curbside recycling policies efficient? Resour. Conserv. Recycl. 2011, 55, 325-334. [CrossRef] 
37. Tai, J.; Zhang, W.; Che, Y.; Feng, D. Municipal solid waste source-separated collection in China: A comparative analysis. Waste Manag. 2011, 31, 1673-1682. [CrossRef] [PubMed]

38. Scheinberg, A.; Spies, S.; Simpson, M.H.; Mol, A.P.J. Assesing urban recycling in low- and middle-income countries: Building on modernised mixtures. Habitat. Int. 2011, 35, 88-198. [CrossRef]

39. Godfrey, L. Facilitating the improved management of waste in South Africa through the national waste information system. Waste Manag. 2008, 28, 1660-1671. [CrossRef] [PubMed]

40. Purnell, G. National Waste Quantification and Waste Information System; Department of Environmental Affairs: Pretoria, South Africa, 2009.

41. Ramukhwatho, F.R.; Du Plessis, R.; Oelofse, S. Household food wastage in a developing country: A case study of Mamelodi Township in South Africa. In Proceedings of the WasteCon 2014 22nd Waste Management Conference and Exhibition: Wired for Waste-Value, Grow, Sustain, Somerset West, South Africa, 6-10 October 2014; pp. 468-475.

42. Ramukhwatho, F.R. An Assessment of the Household Food Wastage in a Developing Country: A Case Study of Five Areas in the City of Tshwane Metropolitan Municipality, Gauteng Province, South Africa. Ph.D. Thesis, University of South Africa, Pretoria, South Africa, 2016.

43. Bernardes, C.; Günther, W.M.R. Generation of domestic solid waste in rural Areas: Case study of remote communities in the Brazilian Amazon. Hum. Ecol. 2014, 42, 617-623. [CrossRef]

44. Janmaimool, P.; Denpaiboon, C. Evaluating determinants of rural villagers' engagement in conservation and waste management behaviors based on integrated conceptual framework of pro-environmental behaviour. Life Sci. Soc. Policy 2016, 12, 12. [CrossRef] [PubMed]

45. Zeng, C.; Niu, D.; Li, H.; Zhou, T.; Zhao, Y. Public perceptions and economic values of source-separated collection of rural solid waste: A pilot study in China. Resour. Conserv. Recycl. 2016, 107, 166-173. [CrossRef]

46. Mukherji, S.B.; Sekiyama, M.; Mino, T.; Chaturvedi, B. Resident Knowledge and Willingness to Engage in Waste Management in Delhi, India. Sustainability 2016, 8, 1065. [CrossRef]

47. Fiorillo, D. Household waste recycling: National survey evidence from Italy. J. Environ. Plan. Manag. 2013, 56, 1125-1151. [CrossRef]

48. Parrot, L.; Sotamenou, J.; Dia, B.K. Municipal solid waste management in Africa: Strategies and livelihoods in Yaoundé, Cameroon. Waste Manag. 2009, 29, 986-995. [CrossRef] [PubMed]

49. Statistics South Africa (StatsSA). Unemployment Levels in South Africa 2017. Available online: www.statssa. gov.za (accessed on 6 September 2017).

50. Provincial Planning and Development Commission (PPDC). A Report for the Assessment of Waste Disposal Sites in the Province of KwaZulu-Natal 2004; A Study Commissioned by the Provincial Planning and Development Commission (PPDC); Prepared by Sivest-Environment and Town Planning Division; Provincial Planning and Development Commission: Pietermaritzburg, South Africa, 2004.

51. South African Treasury. Delivering Municipal Services in Rural Areas. 2012. Available online: www. treasurygov.za (accessed on 6 September 2017).

52. Institute of Natural Resources. Umkhanyakude District Municipality: Local Economic Development Initiative. 2003. Available online: http:/ /www.led.co.za/sites/default/files/umkhanyakude_led_report.pdf (accessed on 20 September 2017.

53. Umkhanyakude District Municipality (UDM). Integrated Development Plan (IDP Review 2014/2015); Umkhanyakude District Municipality (UDM): KwaZulu-Natal, South Africa, 2014.

54. Umkhanyakude District Municipality (UDM). Integrated Development Plan (IDP Review 2016/2017), Final 3rd Generation. 2016. Available online: www.ukdm.gov.za/ (accessed on 25 February 2017).

55. Zululand District Municipality. Integrated Development Plan (IDP Review 2014/2015); Zululand District Municipality: KwaZulu-Natal, South Africa, 2014.

56. Zululand District Municipality. Integrated Development Plan (IDP Review 2011/2012); Zululand District Municipality: KwaZulu-Natal, South Africa, 2011.

57. Leedy, P.D.; Ormrod, J.E. Practical Research Planning and Design, 10th ed.; Pearson Education: Upper Saddle River, NJ, USA, 2005.

58. Huang, P.; Zhang, X.; Deng, X. Survey and analysis of public environmental awareness and performance in Ningbo, China: A case study on household electrical and electronic equipment. J. Clean. Prod. 2006, 14, 1635-1643. [CrossRef] 
59. Zhuang, Y.; Wu, S.W.; Wang, Y.L.; Wu, W.X.; Chen, Y.X. Source separation of household waste: A case study in China. Waste Manag. 2008, 28, 2022-2030. [CrossRef] [PubMed]

60. Babaei, A.A.; Alavi, N.; Goudarzi, G.; Teymouri, P.; Ahmadi, K.; Rafiee, M. Household recycling knowledge, attitudes and practices towards solid waste management. Resour. Conserv. Recycl. 2015, 102, 94-100. [CrossRef]

61. Revelle, W.; Zinbarg, R. Coefficients Alpha, Beta, Omega, and the glb: Comments on Sijtsma. Psychometrika 2009, 74, 145-154. [CrossRef]

62. Statistics South Africa (StatsSA). Census 2011. Population in the Local Municipalities, KwaZulu-Natal Province of South Africa. 2011. Available online: http:/ / www.statssa.gov.za/ (accessed on 31 August 2017).

63. Statistics South Africa (StatsSA). Census 2011. Municipal Report-KwaZulu Natal/Statistics South Africa; Report No. 03-01-53; Statistics South Africa: Pretoria, South Africa, 2012.

64. Statistics South Africa (StatsSA). Monthly Earnings of South Africans, 2010. Statistics South Africa: Pretoria, South Africa. Available online: www.statssa.gov.za (accessed on 14 August 2017).

65. Taghipour, H.; Amjad, Z.; Aslani, H.; Armanfar, F.; Dehghanzadeh, R. Characterizing and quantifying solid waste of rural communities. J Mater. Cycles Waste Manag. 2016, 18, 790-797. [CrossRef]

66. Bhagwandin, G. A Study of the Current Status of Waste Management and Minimisation Initiatives in Two District Municipal Areas of the Gauteng Province (West Rand and Sedibeng). Master's Dissertation, University of Johannesburg, Johannesburg, South Africa, 2013.

67. Liebenberg, C.J. Waste Recycling in Developing Countries in Africa: Barriers to Improving Reclamation Rates. In Proceedings of the Eleventh International Waste Management and Landfill Symposium, Cagliari, Italy, 1-5 October 2007; pp. 1-9.

68. Vicente, P.; Reis, E. Factors influencing households' participation in recycling. Waste Manag. Res. 2008, 26, 140-146. [CrossRef] [PubMed]

69. Afroz, R.; Hanaki, K.; Hasegawa-Kurisu, K. Willingness to pay for waste management improvement in Dhaka city, Bangladesh. J. Environ. Manag. 2009, 90, 492-503. [CrossRef] [PubMed]

70. Mbiba, B. Urban solid waste characteristics and household appetite for separation at source in Eastern and Southern Africa. Habitat Int. 2014, 43, 152-162. [CrossRef] 